\title{
The relationship between employees' self-esteem and pertinacity
}

\author{
Jafar Beikzad, Mostafa Abbasalizadeh, Saeid Ghorbannejad Maleki*, Roghie Fathi Bonabi
}

Department of Management, Islamic Azad University, Bonab Branch, Bonab, Iran

\begin{tabular}{|c|c|}
\hline A R T I C L E I N F O & A B S T R A C T \\
\hline $\begin{array}{l}\text { Article history: } \\
\text { Received July } 31,2011 \\
\text { Received in Revised form } \\
\text { September, 12, } 2011 \\
\text { Accepted } 16 \text { September } 2011 \\
\text { Available online } \\
\text { 19 September } 2011 \\
\text { Keywords: } \\
\text { Self steam } \\
\text { Pertinacity } \\
\text { Commitment } \\
\text { Control } \\
\text { Defiance }\end{array}$ & $\begin{array}{l}\text { The purpose of this paper is to evaluate the relationship between employees' of East Azarbaijan } \\
\text { Melli bank (zone 10) self-esteem and pertinacity. For this reason, employee's self-esteem was } \\
\text { arranged in two dimensions, which are consistency solidity, emotional inconsistency and } \\
\text { pertinacity. The questionnaire is based on Kobasa theory including three sides including } \\
\text { commitment, control and defiance. There are two basic and three subsidiary theories. Employee } \\
\text { of East Azarbaijan Melli bank (zone 10) is statistical society of this research, which includes } 80 \\
\text { people. Reference to restricted volume of statistical society, total statistical society is concerned } \\
\text { as under evaluation society. The tool of data gathering is two questionnaires, which are } \\
\text { Aizenc's self-esteem questionnaire and Kobasa's pertinacity standard questionnaire, which are } \\
\text { delivered for evaluating society after perpetuity and justifiability determination. The descriptive } \\
\text { statistical methods are used for collected questionnaires analyze. Thus, the descriptive statistical } \\
\text { method was used to summarize, to categorize and to interpret statistical data's. In addition, } \\
\text { statistical tests such as Pearson and Freidman's coherency R are used to test the hypothesis of } \\
\text { research. The results indicate that there is a meaningful relationship between self-esteem and } \\
\text { pertinacity and its sides on employees of East Azarbaijan Melli bank (zone 10). They present } \\
\text { maximum relationship between self-esteem and pertinacity control and minimum relationship } \\
\text { between pertinacity commitment dimensions. }\end{array}$ \\
\hline
\end{tabular}

(C) 2012 Growing Science Ltd. All rights reserved.

\section{Introduction}

The Human wants to know himself as gentleman, worthy and creditable and needs to be supported and commended from others and like to be pride for himself and others. When he/she does his jobs successfully he/she feels worthfulness and aplomb, which directs him on this opinion that: his success depends on the results of his/her jobs so he feels stress and worry about life and work because he/she believes his/her works determines his/her success or failure. Self-esteem is a term implemented in psychology to reflect someone's overall evaluation or appraisal of his or her own worth. The person who has low self-esteem does not feel confident and he/she will be more influenced through social medication and concern it more than others do.

During the past few years, there have been tremendous efforts to study the relationship between selfesteem and pertinacity (Jamieson, 1997; Cole et al., 2004; Levin, 2004; McPherson et al., 2006;

* Corresponding author. Tel: +098912 2582448

E-mail addresses: saeid.Maleki141@Gmail.com (S. Maleki) 
Stinson et al., 2010; Vess et al., 2011). McMullin and Cairney (2004) studied the relationships among self-esteem, age, class, and gender by looking whether relationships between self-esteem and gender are similar between age and class groups. Contrary to past research, which recommends that age does not significantly influence on self-esteem or that self-esteem increases with age. The report also finds that levels of self-esteem are lower in older age groups for both men and women. In addition, according to their results, in all age groups, women have lower levels of self-esteem than men do. Social class does not affect levels of self-esteem for young men or women but it does for those in middle age and older age groups. From middle age on, social classes diverge in their levels of selfesteem such that men and women from lower social classes experience the lowest levels of selfesteem.

LeRouge et al. (2006) studied the impact of role stress fit and self-esteem on the job attitudes of IT professionals. They implemented person-job fit theory to study the relationships between the match in IT developers' preferred and perceived actual role stress with job satisfaction and organizational commitment. Self-esteem was investigated as either a potential moderator or mediator of those relationships. Results from investigation accomplished by IT developers in 12 Fortune 500 firms revealed that role stress fit was positively associated with both job satisfaction and organizational commitment and that self-esteem substantially moderated the relationship between role stress fit and job satisfaction.

Grumm et al. (2009) performed three experiments to investigate asymmetrical patterns of implicit and explicit self-esteem change. They studied the influence of knowledge about the own self, which is momentarily salient as well as the effect of affective valence associated with the self in memory on implicit and explicit self-esteem. They reported that while evaluative conditioning changed implicit but not explicit self-esteem, thinking about the own self altered explicit but not implicit self-esteem. They also showed that the effect of evaluative conditioning could spill over to the explicit level when participants are required to concentrate on their feelings before making their self-report judgments. Yaratan and Yucesoylu (2010) studied self-esteem, self-concept, self-talk and significant others' statements in fifth grade students. They reported a significant difference in the self-esteem of the students with respect to school type but not with respect to gender. Negative statements made by significant others, but were substantially various for male and female students.

This paper evaluates the relationship between pertinacity and self-esteem. Self-esteem is one of the most important issues and many people consider it as basic element in people's emotional and social consistency. Self-esteem is one of psychological health signals and when a person has good feeling about himself, he/she can handle difficulties better. The statement of self-esteem is a basic need, which means that self-esteem is necessary for human growth and evolution. The organization of this paper first discusses all the related issues in section 2. Section 3 is devoted to details of our analysis and finally concluding remarks are given in the last to summarize the contribution of the paper.

\section{Self-esteem and pertinacity}

In order to evaluation the relationship between self-esteem and pertinacity in employees of East Azarbaijan Melli bank (zone10) pertinacity regulated as three dimensions, which are as follows,

1- Commitment: commitment feelings, interest or same direction with person's actions. In fact, commitment is at the reverse side of self-strangeness.

2- Control: prediction ability or life events restrain and opposite point of inability.

3- Defiance: challenging or knowing changes natural and opposite point of unsafe feeling.

In addition, self-esteem regulated as two dimensions based on Aizenk theory, which are as follows,

1- Consistency solidity: It is one of personality composer elements composed by many features such as self-esteem, pleasure, peace, stability, etc. 
2- Emotional inconsistency: It is one of personality composer elements consists of many features such as scorn feeling, worry, depression, self depreciation, etc.

Today organizational development needs reaching to higher quality and innovation and costs providence. Awareness of employees personal features and believe to effects of some features, which encourage human behaviors so organizations excellence, is imperative. Attending to employees' selfesteem features and trying to motivate them is one of the basic individual's progresses in organization. Attending to personality attributes may cause to increase efficiency and effectiveness in organizations. Therefore, individual's self deduction is effective by how much and how conditions and supervisors could contribute to their opinions.

The main purpose of this paper is to evaluate the relationship between employees of East Azarbaijan Melli bank (zone10) self-esteem and their pertinacity and we look for:

1- Analyzing employees' self-esteem and commitment,

2- Analyzing employees' self-esteem and control,

3- Analyzing employees' self-esteem and defiance,

4- Analyzing difference and priority of employees' self-esteem relationship measure with their pertinacity.

\subsection{Theatrical framework of research}

At present research Aizenk's theory about self-esteem and Kobasa's theory about pertinacity have been used to evaluate the relationship between employees' of East Azarbaijan Melli bank (zone 10) self-esteem and pertinacity. The present research is a survey as methodological view and is applied as goal view. Statistical society number is 80 employees of Melli bank of East Azarbaijan. Regarding to restricted volume of statistical society, all of statistical society considered as under evaluating society.

Table 1

Statistical Society employees' number

\begin{tabular}{|c|c|c|c|c|c|c|c|}
\hline Branch & $\begin{array}{c}\text { Total } \\
\text { Employee } \\
\text { Number }\end{array}$ & CEO & $\begin{array}{c}\text { Service } \\
\text { Employees }\end{array}$ & $\begin{array}{c}\text { Distributed } \\
\text { Questionnaire }\end{array}$ & $\begin{array}{c}\text { Collected } \\
\text { Questionnaire }\end{array}$ & $\begin{array}{c}\text { Present } \\
\text { Employees }\end{array}$ & $\begin{array}{l}\text { Colleagues } \\
\text { at training }\end{array}$ \\
\hline Bonab Central & 45 & 1 & 7 & 33 & 26 & 33 & 4 \\
\hline Bonab IAU & 5 & 1 & 1 & 2 & 2 & 2 & 1 \\
\hline Bonab Modarres & 9 & 1 & 1 & 6 & 4 & 6 & 1 \\
\hline Bonab Emam Blv & 5 & 1 & 1 & 3 & 3 & 3 & 0 \\
\hline Bonab Moallem & 6 & 1 & 1 & 4 & 2 & 4 & 0 \\
\hline Bonab Zargaran & 7 & 1 & 1 & 5 & 5 & 5 & 0 \\
\hline Ajabshir Central & 14 & 1 & 2 & 10 & 10 & 10 & 1 \\
\hline Ajabshir Kosar & 6 & 1 & 0 & 5 & 5 & 5 & 0 \\
\hline AzarshahrCentral & 16 & 1 & 1 & 14 & 12 & 14 & 0 \\
\hline Azarshahr Madani & 4 & 1 & 1 & 2 & 2 & 2 & 0 \\
\hline Mamaghan & 7 & 1 & 1 & 4 & 4 & 4 & 1 \\
\hline Gogan & 7 & 1 & 1 & 5 & 5 & 5 & 0 \\
\hline Sum & 131 & 12 & 18 & 93 & 80 & 93 & 8 \\
\hline
\end{tabular}

The study has designed a questionnaire consists of two parts. In the first part, we gather the general information of the participants such as gender, age, marital status, educational level, work history. The second part of the questionnaire includes self-esteem questions based on Aizenk's theory, which have been used on Likert scale framework. There are 30 questions associated with this part, which are summarized in Table 2. The other section of the survey is based on Kobasa's theory consists of 50 questions. 
Table 2

Self-esteem dimensions and number of related questions

\begin{tabular}{llll}
\hline & Dimensions & Number Of Questions & Questions Ranking \\
\cline { 2 - 4 } Self Steam & consistency solidity & 9 & $22 \sim 30$ \\
& $\begin{array}{l}\text { Emotional } \\
\text { Inconsistency }\end{array}$ & 21 & $1 \sim 21$ \\
\hline Sum of Self-esteem Questions & 30 & \\
\hline
\end{tabular}

Professors and experts who made the necessary comments accepted justifiability of questionnaire. In order to estimate questionnaire perpetuity, Cronbach Alpha (Cronbach, 1951) test has been used and the values of this test for self-esteem questions perpetuity and pertinacity questions were 0.83 and 0.81 , respectively. These statistics states that questions have high coherency and research questionnaire has high perpetuity.

\subsection{Research hypothesis}

The hypothesis of this research consists of two parts, which are as follows,

There is a meaningful relationship between employees' of East Azarbaijan Melli bank (zone 10) selfesteem and pertinacity.

- There is a meaningful relationship between employees' of East Azarbaijan Melli bank (zone 10) self-esteem and commitment side of pertinacity.

- There is a meaningful relationship between employees' of East Azarbaijan Melli bank (zone 10) self-esteem and control side of pertinacity.

- There is a meaningful relationship between employees' of East Azarbaijan Melli bank (zone 10) self-esteem and defiance side of pertinacity.

There is a meaningful relationship between employees' of East Azarbaijan Melli bank (zone 10) selfesteem and pertinacity dimensions.

\section{Results and discussion}

In order to analyze the collected data from gathered questionnaires descriptive and deductional statistical methods have been used. At the deduction level, the Pearson and Friedman's coherent R test has been used for hypothesis examination.

\subsection{Statistical description of demographic questions}

According to the results, we understand that $98.75 \%$ of statistical sample are male and $1.25 \%$ are female. About $15 \%$ of statistical sample are single and $85 \%$ are married, $32.5 \%$ of statistical sample are under 30 years old and $27.5 \%$ are between $31 \& 35$ years old. In addition, $13.75 \%$ of statistical sample are between $36 \& 40$ and $18.75 \%$ are between $41 \& 45$ years old. Finally, $6.25 \%$ of statistical sample are more than 45 years old and $1.25 \%$ did not provide any answer.

On other side, $25 \%$ of statistical sample maintained high school degree, $11.25 \%$ hold bachelor degree, $60 \%$ had master degree and $3.75 \%$ had some graduation degrees from academic level.

Also there were $12.5 \%$ under 5 years of job experience, $38.75 \%$ had between 5 to 10 years job experiences, $18.75 \%$ maintained between 11 to 15 years job experience, $17.5 \%$ between 16 and 20 years and $12.5 \%$ had more than 20 years job experience. Table 3 shows the details of our survey based on different criteria of self-esteem, commitment, control, defiance and pertinacity. 
Table 3

Descriptive statistical results of research variables

\begin{tabular}{|c|c|c|c|c|c|}
\hline Statistics & Self-esteem & Commitment & Control & Defiance & Pertinacity \\
\hline Number of observations & 80 & 80 & 80 & 80 & 80 \\
\hline No Answer & 0 & 0 & 0 & 0 & 0 \\
\hline Average & 20.72 & 19.06 & 31.45 & 28.91 & 79.42 \\
\hline Mean & 21 & 19 & 31.5 & 29.5 & 79 \\
\hline Mod & 25 & 20 & 29 & 31 & 66 \\
\hline Deviation Criteria & 4.45 & 4.82 & 5.76 & 5.33 & 13.03 \\
\hline Variant & 19.88 & 23.27 & 33.33 & 28.46 & 169.94 \\
\hline Ranking & 19 & 21 & 22 & 44 & 58 \\
\hline Minimum & 10 & 9 & 19 & 19 & 49 \\
\hline Maximum & 29 & 30 & 41 & 42 & 107 \\
\hline
\end{tabular}

Based on the collected information, it is clear that average of self-esteem independence variable of organization is 20.72 and also average numbers for Commitment, Control, Defiance, and Pertinacity are 19.06, 31.45, 28.91 and 79.42, respectively. In order to determine the relationship between selfesteem and pertinacity and its dimensions, Pearson's Coherent $R$ has been used. Table 5 summarizes details of our survey.

Table 5

Pearson's R test for determination of coherent between employee's pertinacity and its dimensions on their self-esteem

\begin{tabular}{lll}
\hline Variable & Meaningfully Level & Self Steam \\
\hline Pertinacity & 0.000 & 0.573 \\
Commitment Dimension & 0.000 & 0.429 \\
Control Dimension & 0.000 & 0.584 \\
Defiance Dimension & 0.000 & 0.380 \\
\hline
\end{tabular}

In order to determine the relationship of self-esteem and employee pertinacity Friedman's test has been used and the average ranking for Commitment, Control and Defiance are 1.36, 3.70 and 3.19, respectively, and the Chi-Square has been calculated as 182.053. As we can observe from these statistical observations, there is a meaningful relationship between self-esteem and three dimensions including commitment, control and defiance in employees of East Azarbaijan Melli Bank (zone10). In addition, the Chi-Square is also statistically meaningful, which means meaningful difference between self-esteem relationship measure and any dimension of employees' pertinacity. Therefore, organization managers must create some opportunities to make an environment changes for their employees who have competitions for their progress. Note that employees' success depends on personal features, attributes and skills, knowledge and necessary experiences and these issues happen when there is a support on behalf of the management team. Based on the results we can increase employees' pertinacity and increase their self-esteem using the following guidelines,

- Easy access to necessary information,

- Familiarize employee with rules and regulations,

- Create more motivation to learn more,

- Be open for their suggestions and comments,

- Provide positive background for feedbacks.

\section{Conclusion}

In this paper, we have presented an empirical study to measure the relationship between self-esteem and pertinacity. The present study of this paper designed and distributed some questionnaire among employee who worked for East Azarbaijan Melli Bank (zone10). The questionnaire gathered the 
necessary responses from the employees' personal characteristics as well as their feedback on different questions on self-esteem and pertinacity. The results indicated that there was a meaningful relationship between self-esteem and three dimensions including commitment, control and defiance in employees of East Azarbaijan Melli Bank (zone10). In addition, the Chi-Square is also statistically meaningful which means meaningful difference between self-esteem relationship measure and any dimension of employees' pertinacity.

\section{Acknowledgment}

The authors would like to thank Islamic Azad University of Bonab for financially supporting this research work.

\section{References}

Cronbach, L. J. (1951). Coefficient alpha and the internal structure of tests. Psychometrika, 16(3), 297-334.

Cole, M. S. (2004). Student Learning Motivation and Psychological Hardiness: Interactive Effects on Students' Reactions to a Management Class. Journal of Academy of Management Learning and Education, 3(1), 64-85.

Grumm, M., Nestler, S., \& von Collani, G. (2009). Changing explicit and implicit attitudes: The case of self-esteem. Journal of Experimental Social Psychology, 45(2), 327-335.

Jamieson, L. (1997). Intimacy: Personal relationships in modern society. Cambridge: Policy Press.

Levin, I. (2004). Living apart together: A new family form. Current Sociology, 52, 223-240.

LeRouge, C., Nelson, A., \& Blanton, J. E. (2006).The impact of role stress fit and self-esteem on the job attitudes of IT professionals. Information \& Management, 43(8), 928-938.

Likert, R. (1932). A Technique for the Measurement of Attitudes. Archives of Psychology, 140, 1-55.

McPherson, M., Smith-Lovin, L., \& Brashears, M. (2006). Social isolation in America: Changes in core discussion networks over decades. American Sociological Review, 71, 353-375.

McMullin, J.A., \& Cairney, J. (2004). Self-esteem and the intersection of age, class, and gender. Journal of Aging Studies, 18(1), 75-90.

Yaratan, H., \& Yucesoylu, R. (2010). Self-esteem, self-concept, self-talk and significant others' statements in fifth grade students: Differences according to gender and school type. ProcediaSocial and Behavioral Sciences, 2(2), 3506-3518.

Stinson, D.A., Logel, C., Holmes, J.G., Wood, J.V., Forest, A.L., Gaucher, D., Fitzsimons, G.M., \& Kath, J. (2010). The Regulatory Function of Self-Esteem: Testing the Epistemic and Acceptance Signaling Systems. Journal of Personality and Social Psychology, 99(6), 993-1013.

Vess, M., Arndt, J., \& Schlegel, R.J. (2011). Abstract construal levels attenuate state self-esteem reactivity. Journal of Experimental Social Psychology, 47(4), 861-864. 